V. Kovalevska-Slavova,

Doctor in Philology,

Odessa Regional Institute for Public Administration of the National Academy for Public Administration under the President of Ukraine, Ukrainian and Foreign Languages Department Associate Professor

\title{
POLITICAL PATHOGENIC MEGADISCOURSES NEUTRALIZATION: TROLLING STRATEGY
}

The article is aimed at specifying and visualizing the strategies and tactics of neutralizing the negative effects of the pathogenic political megadiscourses. On top of that, it explores the suggestion linguistic implementation features, having been examined basing on the European political leaders' speeches and news texts, and emphasizes the specificity of trolling strategy, which is aimed either at escalating the emotionality and falsity of the information presented in the original textual array, or at bringing the information having been presented in the original array to the absurd, which would minimize the rationality of the original array perception, and subsequently - trust in the original array, and in the addressee of these arrays (later on). The trolling strategy is optimal in the framework of neutralizing the pathogenic arrays having been created in the fake news paradigm, given these arrays' orientation onto presenting knowingly false information in order to escalate tensions in the information space and destabilize the situation as a whole. The author presents and validates examples of using all the tactics of this strategy (rough (destructive) trolling or flaming, constructive trolling, exaggeration / reduction, wiki-trolling, "big lies" tactics, sockpuppetting tactics), which follow all the features of the original pathogenic array, including the dominant influence markers, as well as the original array's suggestiveness realization peculiarities, which allows (when presenting the neutralizing array to the same target audience that has already been affected by the original array) to reduce or neutralize the harmful effects of the original pathogenic array. The paper also outlines the prospects for further research in this area given its fundamental importance not only for identifying the basic strategies for constructing pathogenic arrays and in-depth mechanisms of their formulation and, consequently, their impact on recipients, but also ways to counteract each type of such megadiscourses, thus optimizing Ukraine's information space in the conditions of information war currently being carried out not only in our country, but in the numerous world countries, as well.

Key words: political megadiscourse, pathogenic text, neutralization strategy, information wars, trolling, neurolinguistic programming, suggestion.

Problem statement and the latest scientific researches and publications analysis. Ukraine, like all other developed countries of the world, currently finds itself within the paradigm of a netocratic society $[2 ; 8 ; 16]$, where the data is the main and most crucial 
commodity, in contrast to, for example, technologies in the industrial phase and products in agricultural one, so "he who owns information, owns the world" [15]. Exclusive access to data provides power over the rest of society [2], thus giving maximum weight to the netocratic discourse (information paradigm of communication), one of the features of which (along with manufacturability, reducing the life cycle of information and thus increasing the amount of information needed for the functioning of society, etc.) is a pervasive suggestibility and pathogenicity, which characterize this discourse as "one that generates painful deviations" [10, p. 35] and "causes or, in the opinion of experts, is capable of causing harm to the moral and mental health of an individual, nation, state, humanity" [10, p. 209].

Given that suggestibility and pathogenicity are one of the defining, key characteristics of this modern society and the discourse produced by it, they apply to all its species and types, including political, which is the object of our study and which L. L. Slavova defines as "a set of all speech acts, as well as the rules of public policy, which were formed in accordance with existing traditions and tested by experience" [12, p. 67]. The subject of our study, which is aimed at detailing and illustrating strategies and tactics for neutralizing the negative effect of the pathogenic political megadiscourse, is the specifics of the linguistic implementation of pathogenicity in political discourse. In order to achieve this goal, it is necessary to perform the following tasks: characterize the very concept of strategies and tactics to neutralize the negative effect of the pathogenic political megadiscourse; identify the main strategies and describe the trolling strategy in as much detail as possible, since it is the focus of this scientific work; identify appropriate tactics within the trolling strategy and illustrate them with valid examples; outline the prospects for further development in this area. The actual material of the study are the European politicians' speaches, political programs, dialogues at press-conferences, etc., as well as the news arrays and corresponding Internet posts (about 200 units of each type having been recorded during $2006-2020$.).

Main research material presentation. Having determined the basic provisions of classifying and identifying pathogenicity within the political megadiscourses, as well as characterizing the basic algorithm for the analysis of pathogenic megadiscourses, aimed at neutralizing the negative effect of pathogenic political megadiscourses in previous works [7; $16 ; 17 ; 18 ; 19 ; 20]$, it is necessary to emphasize that the actual neutralization of the negative effect of these arrays occurs at the third stage of the according ICN-algorythm by choosing the appropriate strategy (defining line of rules and sequence of communicative actions within the implementation of the algorithm of pathogenic political megadiscourse neutralization, which is aimed at neutralizing their negative effects, implemented in specific tactics, and based on the preliminary identification and classification of pathogenic political megadiscourses) or tactics (clearly defined set of specific techniques for implementing the strategy of neutralizing the negative effect of pathogenic political megadiscourse, which is aimed at counteracting their negative effect).

So, in our previous articles, we've offered three basic strategies: refutation, filling gaps and trolling $[; 16 ; 17 ; 18 ; 19 ; 20]$, and since the latter one is the focus of our current scientific work, it is necessary to detail its specificity and peculiarities.

Trolling strategy is aimed either at escalating the emotionality and falsity of the information presented in the original textual array, or at bringing the information having been presented in the original array to the absurd, which would minimize the rationality of the original array perception, and subsequently - trust in the original array, and in the addressee of these arrays (later on). The trolling strategy is optimal in the framework of neutralizing the pathogenic arrays having been created in the Fake Attack information war (IW) paradigm, given these arrays' orientation onto presenting knowingly false information in order to escalate tensions in the information space and destabilize the situation as a whole. It is the information constructed within the framework of this IW type that usually does not 
correspond to reality, so bringing it to the absurd becomes quite simple, given the inherent internal contradictions, which makes it possible to reduce the index of negativity of the original array.

Trolling usually refers to "the development of deliberately provocative messages to provoke conflicts between members of the online community, a "wave of edits" (active targeted intervention into the messages text within the context of propaganda and imposition of one's own position), and to lead users into meaningless confrontation" [11, p. 135] or "provocation to achieve a certain goal" [4, p. 174].

Researchers elicit political trolling as a separate type of trolling, since it differs from all the other types in that it "aims to promote ones' own ideas, in this case - the ideas of the superiority of ones' political power and discredit competitors" [5, p. 89], and is usually realized in the paradigm of the so-called "subtle" trolling, when the troll, "affecting the personal and professional qualities of the opponent, influencing him, throws off balance and causes the appropriate reactions expected by the troll" [1, p. 51].

Within the context of our work, aimed at studying the suggestive aspects of pathogenic texts and mechanisms for neutralizing the negative effects of these arrays, the principal feature of trolling is the potential suggestiveness of texts generated in the process, which requires a certain supplementation of the existing definitions. Thus, in our work, we will define trolling as "the development of deliberately provocative messages to neutralize the negative effects of pathogenic political texts by either escalating the emotionality and falsity of the information provided in the original text, or bringing the information provided in the original text to absurdity, which will make it possible to minimize the rationality of the original text perception, and later - the trust in both the original text in particular, and in the trustworthiness of the addressee of these texts in general».

Thus, within the trolling strategy we single out the following tactics:

1. Rough (destructive) trolling or flaming tactics that correlate with the definition of "thick" trolling, the initiators of which behave quite acerbically and even rudely, their opinion is radically different from the opinion of the local majority ... which best serves their goal, which is to cause chaos and draw attention to themselves" [5, p. 88] (named by analogy with such a type of trolling as flaming, which is understood as "the act of posting an image, often with the addition of obscene swearing or other offensive speech on social networking sites" [14]). This is a tactic aimed at deliberately diminishing the value of the original text through aggressive criticism, often offensive to the author / distributor of the text, deliberately misspelling the names and titles used in the original text, and even threats against it, which ultimately aims to shift the focus from the information actually provided in the original text to the flamer's message due to its maximum emotional saturation caused by increased emotionality and aggression.

2. Constructive trolling tactics that correlate with the definition of "subtle" trolling, a supporter of which "acts on thevery brink of the rules adopted in the place where he acts, without violating them directly, and often forcing the administration to exceed authority or violate its own rules", utilizing "deep knowledge in psychology that allows them to influence people using more sophisticated methods" [5, p. 88 - 89]. Their goal is to purposefully bring the original text to the absurd to reduce both its negative effect and trust in its author. As part of the tactics of constructive trolling, we distinguish the following:

a) exaggeration / reduction tactic that inversely correlates with P. Ekman's exaggeration lies type, when we "speak the truth in such a way that it is impossible to believe it", which is extremely effective because it "threatens to ridicule the opponent in case further action. A mocking intonation or facial expression in such a case can also contribute to deception" [13, p. 29]. In the framework of trolling, this tactic will be most effective in the context of the pathogenic arrays belonging to both the "Fake Attack" (because it is to neutralize this type of 
IW that we mostly offer to use these types of strategies) and "Mountains out of Molehills" (because it usually has certain quantifiers, which can be reduced or increased according to the purpose of using tactics to create the effect of absurdity) IW types;

b) Wiki-trolling tactic, which is related to the definition of a Wiki-troll as "a person who reposts information from Wikipedia (or other reliable sources such as historians' blogs, etc.), without giving any emotional value to this information. The information being posted is generally true, but it is also used in the wrong context to draw the wrong conclusions. [22, p. 62]. In the context of our development, we define the Wiki-trolling tactics as such which does not provide comments on the actual original text or its author, but simply delivers the most reliable information from the most reliable resources, which, however, creates the effect of absurdity and nullifies rationality of the original text.

c) the "Big Lie " tactic, which is aimed at bringing the information reported in the original text to an absolute absurdity, O.V. Kravchenko defining it as "non-normative language construction that does not presuppose a special symbolic convention and does not correspond to a real discursive situation, one which consists of significant units and semantically contradicts the formed linguistic picture of the world" [9, p. 142]. The name " Big Lie " is an allusion to the propaganda technique named "große Lüge", which is defined as "a lie so "huge" that no one will believe that someone had the courage to distort reality so shamelessly" [3], emphasizing that "people are more likely to believe a big lie than a small one; and if you repeat it often enough, sooner or later people will believe it" [21]. This emphasizes that this tactic focuses on maximum distortion of reality created by the original array, which, however, may seem even more plausible than the original array, by increasing the degree of its absurdity, and that even the maximum lie, which is branded as untrue, still leaves an imprint in the mass consciousness.

It should be noted that the difference between this tactic and the exaggeration / reduction one is that, within the latter one, only the action or quantifier directly mentioned in the original text is exaggerated, while in the framework of the "Big Lie", all the profound contradictions present in the original text are absurdly exaggerated. We also emphasize that we are aware of the ideological focus of the cited works and in no way support the positions set out in them, however, in order to emphasize our technique of neutralizing the pathogenic political texts' negative effect, we consider it necessary to appeal to some of their provisions, as this work is a center of certain norms and motivations that are unacceptable for the Ukrainian society, which, nevertheless, are used in the aggressor country's propaganda, thus motivating the need to formulate appropriate mechanisms to combat them.

d) sockpuppeting tactic (named by analogy with such a kind of Internet trolling as "virtual" or "sockpuppeting" - "an act of creating a fake identity on the Internet to praise, protect or create the illusion of supporting yourself, allies or company" [23]), the mechanics of which, in contrast to previous tactics, the texts of which should be addressed by the actual neutralizer, is to create a fake, fake addressee, who, in order to support of the opinion having been expressed in the original text, has to do this so awkwardly, fanatically and illogically, with so many errors, using theses that can be easily refuted to completely discredit them and all rational arguments in support of them, and put in such an unreliable way, so as to expose oneself to not be trustworthy of the target audience. In the network of this tactic, the illogicality and ignorance of the original text's supporter is in some way transposed to his own idea, which makes it possible to reduce trust in him, and thus reduce the level of the aforementioned texts' pathogenicity.

Thus, it is necessary to illustrate the tactics of refutation strategy on the example of a pathogenic political text. It should be noted that the factual data is involved not because of the author's subjective political preferences, but for an objective scientific analysis of the 
political communication spectrum, as they are components of pathogenic political discourses..

Original pathogenic text:

«Concerning dehumanization. A school, ordinary Zaporizhia school №106. At the Natural Science lessons, teachers suggest children, small children, in the third-fourth grades, to feed titmice because they are yellow-blue, Ukrainian birds, and avoid supporting in every possible way, and even better to hunt bullfinches, because bullfinches are birds that symbolize cursed Russia. Teachers of the Ukrainian school №106 in Zaporizhia, Ukraine have surpassed all the Ukrainian patriotic hysteria available today. In primary school lessons, teachers urged children to save titmice from starvation in winter and destroy bullfinches... According to teachers, the titmouse, with its yellow-blue coloring, symbolizes Ukraine, and the red-breasted bullfinch represents the imperial, red evil named the USSR and its successor - Russia. Every bullfinch in a feeder made by the hands of a Ukrainian child takes food from the titmice (Ukraine). And for this reason, it is desirable not to feed bullfinches. And if you drive away or, for example, shoot a bullfinch with an air weapon, it will be a particularly symbolic gesture in the struggle and victory of all Ukrainians. Many parents are shocked by the children's initiative they brought from the Natural Science lessons») (V. Rogov's statement at the "Special Correspondent" program, TV channel "Russia-2", December 12, 2014).

Given the type of influential units, we can conclude that the use of universal quantifiers, which give the text a restrictive, extensive modality; presuppositions that give the text subjective-objective adequacy and truthfulness, because the recipient subconsciously "deciphers" the meaning having been programmatically embedded in these units; with blurred and artificially expanded semantics due to non-specific words. We also register a large enough number of repetitions that allow us to focus on the repeating element of the text.

Therefore, basing on the text analysis, as well as on the consistency of features and the predominance of the certain complex influence markers, we can conclude about the potential impact and pathogenicity of the analyzed text. It should be noted that one of the main features that makes it possible to identify this text as a pathogenic, and therefore suggestive one, is its fakeness, which has been proved by analyzing the documentary data provided in the text (city, school number, subject name), using fact-checking algorithms (see stopfake.org website).

Having analyzed this text with the algorithm having been presented in our previous scientific articles $[7 ; 16 ; 17 ; 18 ; 19 ; 20]$, we can determine the analyzed text's suggestiveness realization strategy formula and thus classify it as negativization strategy example, which determines the specifics of negativization texts construction.

Table 1.

Possible options for implementing the tactics of trolling strategy

\begin{tabular}{|l|l|}
\hline № & \multicolumn{1}{|c|}{ Приклад вербальної реалізації } \\
\hline 1. & $\begin{array}{l}\text { Who the hell is this Volodymyr Ryhovy anyway? Or what is his surname? An } \\
\text { activist? From Ukraine? Seriously? But any real Ukrainian would kill a person from } \\
\text { Ukraine the day after having heard such statements. Because Ukraine is for } \\
\text { Ukrainians, not for such idiots. And no one in Ukraine has seen this jerk for six } \\
\text { years. Coincidence? I don't think so. What a raging idiot one has to be, and what a } \\
\text { sick idiot, to come up with this. Come on, moron, come "to Ukraine", you will be } \\
\text { shown here what they do with those who tell this in Russia. }\end{array}$ \\
\hline 2a. & $\begin{array}{l}\text { Ukrainians not only do not feed bullfinches, we also poison them every time we can. } \\
\text { We even have a special poison for bullfinches so that a rare bird can reach the } \\
\text { middle of Bandera Avenue. And the titmice are so fat that they can't even fly, but } \\
\text { walk the streets and eat bullfinches we have not poisoned yet. I see it every day. }\end{array}$ \\
\hline
\end{tabular}




\begin{tabular}{|c|c|}
\hline $2 b$ & $\begin{array}{l}\text { And in response to this we will talk about a very, very interesting thing. So. } \\
\text { Schizophrenia is a mental disorder characterized by continuous or relapsing episodes of } \\
\text { psychosis. Major symptoms include hallucinations (typically hearing voices), delusions, } \\
\text { and disorganized thinking. Other symptoms include social withdrawal, decreased } \\
\text { emotional expression, and apathy. Symptoms typically come on gradually, begin in } \\
\text { young adulthood, and in many cases never resolve. There is no objective diagnostic test; } \\
\text { the diagnosis is used to describe observed behavior that may stem from numerous } \\
\text { different causes. Besides observed behavior, doctors will also take a history that } \\
\text { includes the person's reported experiences, and reports of others familiar with the } \\
\text { person, when making a diagnosis. To diagnose someone with schizophrenia, doctors are } \\
\text { supposed to confirm that symptoms and functional impairment are present for six } \\
\text { months or one month. Many people with schizophrenia have other mental disorders, } \\
\text { especially substance use disorders, depressive disorders, anxiety disorders, and } \\
\text { obsessive-compulsive disorder. Most people with schizophrenia are not aggressive, and } \\
\text { are more likely to be victims of violence rather than perpetrators. Schizophrenic people } \\
\text { are commonly exploited and victimized by violent crime as part of a broader dynamic of } \\
\text { social exclusion. People diagnosed with schizophrenia are also subject to forced drug } \\
\text { injections, seclusion and restraint, at high rates. Cannabis-use may be a contributory } \\
\text { factor in the development of schizophrenia, potentially increasing the risk of the disease } \\
\text { in those who are already at risk. The increased risk may require the presence of certain } \\
\text { genes within an individual. Its use is associated with doubling the rate. The use of more } \\
\text { potent strains of cannabis having a high level of its active ingredient } \\
\text { tetrahydrocannabinol (THC), increases the risk further. One of these strains is well } \\
\text { known as skunk. } \\
\text { Have a nice day. }\end{array}$ \\
\hline $2 c$. & $\begin{array}{l}\text { Yes, we repent, we do not support bullfinches and we support tits. But. Note that } \\
\text { bullfinches and tits are not the limit yet. Where is the limit, you can ask? There is } \\
\text { none. If a man in a red T-shirt goes to the store - no Ukrainian store will sell him } \\
\text { food, because you wear red-you love Lenin. If a girl comes on a date with a real } \\
\text { Cossack, her lips painted with red lipstick-every Cossack must kill her and give her } \\
\text { to the tits to eat, because you paint your lips red-you love Putler. By the way, the } \\
\text { name Ruslan is also forbidden in our country, because everyone knows that its root } \\
\text { is Rus, ie Russia, and Russia is the root of all evil. By the way, we now have claims } \\
\text { against Lyudmilas, as well, because they the same as Ruslans. So, let's respect each } \\
\text { other, let's hold on, freedom to the little tits, death to the bullfinches! }\end{array}$ \\
\hline $2 \mathrm{~d}$ & $\begin{array}{l}\text { So it's tru!!!! Mine was also forced to raise these cursed tets! I grow all summer, and } \\
\text { poor bullfinches sit in the sun and are afraid to aproach piple, that's why they've bin } \\
\text { scared so much alredy! We have so much notonly in schools but also in universities, } \\
\text { too, especially in state-owned enterprizez, where in general you has sign a paper } \\
\text { that you hate Russians! If you refuse, then either the sent in Transcarpathia, or if you } \\
\text { persist in delusion, shoot! }\end{array}$ \\
\hline
\end{tabular}

It has to be noted that the neutralized arrays follow all the features of the original one, including the dominant influential markers, as well as the peculiarities original text's suggestiveness realization strategy, which allows (when presenting the text to the same target audience that has already been affected by the original array) to reduce or neutralize the harmful effects of the original pathogenic array.

Research findings and prospects for further research. Thus, having presented and illustrated each tactic of the trolling strategy, while consistently adhering to all the features of the original array in the neutralized ones (including the dominant influential markers, as well 
as the original array's suggestiveness realization strategy details), it can be stated that introducing such technology would allow to reduce or even fully neutralize the harmful effects of the original pathogenic array.

We believe that, since our proposed political megadiscourses' harmful effects strategy neutralization algorithm trolling strategy combines a comprehensive scientific approach within such new sciences as Neurolinguistic Programming, Suggestive Linguistics, SpinDoctoring and Lies Theory, it will allow not only to identify the basic strategies for constructing such arrays and the deep mechanisms of their formulation and, consequently, impact on recipients, but also ways to counteract each of the types of such discourses. This, in turn, will serve not only in detailing the provisions of these sciences, as well as Imageology, Psycholinguistics, PR / GR, Strategic Management, Neuromarketing, etc., but also in possible formation of relevant planning decisions in the field of Ukraine's state information security, which is an important aspect of the any state's information policy, and acquires special significance in the conditions of hybrid and information wars Ukraine currently finds itself in, therefore emphasizing the prospects for further development of this topic, which will be the focus of our further scientific research.

\section{Literature}

1. Акулич М. М. Интернет-троллинг: понятие, содержание и формы. Вестн. Тюмен. гос. ун-та. 2012. №8. С. 47-54.

2. Бард A., Зодерквист Я. Netoкратия. Новая правящая элита и жизнь после капитализма. СПб. : Стокгольмская школа экономики в Санкт-Петербурге, 2004. 252 с.

3. Гитлер А. Моя борьба. Харьков: ООО «Свитовид», 2003. 704 с.

4. Гуменюк Л. Й. Мережевий тролінг як вид комунікативної поведінки. Науковий вісник Львівського державного університету внутрішніх справ. Серія психологічна. 2014. Вип. 1. С. 172 - 180.

5. Данько Ю. А. Феномен «тролінгу» як форма комунікативної Інтернетвзаємодії: політичний контекст. Вісник Національного університету «Юридична академія Украӥни імені Ярослава Мудрого». 2015. № 2 (25). С. 83 - 94.

6. Загнітко А. Сучасний лінгвістичний словник. Вінниця : ТВОРИ, 2020. 920 с.

7. Ковалевська A. B. Алгоритм нейтралізації патогенних текстів в українському інформаційному просторі. Одеська лінгвістична школа: модерні парадигми : колект. моногр. / за заг. ред. Ковалевської Т. Ю. Одеса : ПолиПринт, 2018. С. 175 - 285.

8. Ковалевська T. Ю. Комунікативні аспекти нейролінгвістичного програмування : Монографія. Одеса : Астропринт, 2001. 344 с.

9. Кравченко О. В. Синтаксические механизмы порождения лингвистического абсурда. Известия Российского государственного педагогического университета им. А.И. Гериена. 2009. Вып. 106. С. 141-146

10. Потятиник Б., Лозинський М. Патогенний текст. Львів: Місіонер, 1996. 296 с.

11. Семенов Д. И., Шушарина Г. А. Сетевой троллинг как вид коммуникативной деятельности. Междунар. журн. эксперимент. образования. 2011. №8. С.135 - 136.

12. Славова Л. Л. Мовна особистість лідера у дзеркалі політичної лінгвоперсонології : США - Україна : монографія. Житомир : Вид-во ЖДУ ім. I. Франка, 2012. 360 с.

13. Экман П. Психология лжи. Обмани меня, если сможешь. СПб.: Питер, 2010. $304 \mathrm{c}$.

14. Christensson P. Techterms Computer and Internet Terms Dictionary: «Flaming Definition». URL: https://techterms.com/definition/flaming.

15. Davis $R$. The English Rothschilds. London: Collins, 1983. 272 p. URL: https://mawaratytuger.angelstouch16.com/the-english-rothschilds-book-17581yw.php 
16. Kovalevska A. V. Information Wars' Pathogenic Texts Neutralization Algorithm. Записки з украӥнського мовознавства = Opera in linguistica ukrainiana: Fascicullum. 2018. Вип. 25. С. $227-239$.

17. Kovalevska A. V. Spin-Doctoring in modern political discourse: linguistic aspect. Вісник Харківського національного університету імені В. Н. Каразіна. Серія «Філологія». Вип. 87. 2021. С. 90 - 96.

18. Kovalevska T. \& Kovalevska A. Utilizing the Neurolinguistic Programming Technologies in Foreign languages Teaching Practice in Ukrainian Universities. Arab World English Journal: Special Issue on English in Ukrainian Context. 2020. Pp. 184 - 193. DOI: https://dx.doi.org/10.24093/awej/elt3.16.

19. Kovalevska A., Kovalevska T., Kravchynska T., Hirna N. , Lysenko T. Modern methods and information and communication technologies in the system of teachers' training for vocational education institutions. AD ALTA: Journal of interdisciplinary research. Vol. 10. Issue 01-XVI. Ak. sdr. MAGNANIMITAS: Czech Republic, Hradec Krбlovй. 2021. Pp. $106-114$.

20. Kovalevska A., Kovalevska T., Kutuza N., Lakomska I. Suggestion Algorithm in Advertisement Megadiscourse: Hypnotic Inductors Systematics. Journal of Language and Linguistic Studies. Vol. 17 (Special Issue 2), 2020. Pp. 1294 - 1307.

21. Langer W. C. Office of Strategic Services (OSS) Washington, D.C. With the collaboration of Prof. Henry A. Murr, Harvard Psychological Clinic, Dr. Ernst Kris, New School for Social Research, Dr. Bertram D. Lawin, New York Psychoanalytic Institute. A Psychological Analysis of Adolph Hitler. His Life and Legend. URL: http://web.archive.org/web/20050828111124/http://www.nizkor.org/hweb/people/h/hitleradolf/oss-papers/text/profile-index.html.

22. Spruds A. \& Rožukalne A. Internet Trolling as a hybrid warfare tool: the case of Latvia. Riga, LV: NATO Strategic. URL: https://www.stratcomcoe.org/internet-trollinghybrid-warfare-tool-case-latvia-0.

23. Stone B. \& Ritchel M. The Hand That Controls the Sock Puppet Could Get Slapped. The New York Times. July 16, 2007. URL: https://www.nytimes.com/2007/07/16/technology/16blog.html?ex=1342238400\&en=9a3424 $961 \mathrm{f} 9 \mathrm{~d} 2163 \& \mathrm{ei}=5088 \&$ partner $=$ rssnyt $\&$ emc $=$ rss.

\section{References}

1. Akulich, M. M. (2012), Internet-trolling: ponyatie, soderzhanie i formy [Internet trolling: concept, content and forms], Tyumen State University Herald., Vol. 8., Pp. 47-54.

2. Bard, A., Zoderquist, Ya. (2004), Netokratiya. Novaya pravyashchaya elita $i$ zhizn' posle kapitalizma [Netocracy. The new ruling elite and life after capitalism], Stockholm School of Economics in St. Petersburg, SPb., 252 p.

3. Hitler, A. (2003), Moya bor'ba [My fight], OOO «Svitovid», Khar'kov, 704 p.

4. Humeniuk, L. Y. (2014), Merezhevyi trolinh yak vyd komunikatyvnoi povedinky [Network trolling as a type of communicative behavior], Scientific Bulletin of Lviv State University of Internal Affairs. Psychological series, Vol. 1, pp. $172-180$.

5. Danko, Yu. A. (2015), Fenomen «trolinhu» yak forma komunikatyvnoi Internetvzaiemodii: politychnyi kontekst [The phenomenon of "trolling" as a form of communicative Internet interaction: a political context], Bulletin of the National University "Yaroslav the Wise Law Academy of Ukraine", № 2 (25), Pp. 83 - 94.

6. Zahnitko, A. (2020), Suchasnyi linhvistychnyi slovnyk [Modern linguistic dictionary], TVORY, Vinnytsia, $920 \mathrm{p}$.

7. Kovalevska, A. V. (2018), Alhorytm neitralizatsii patohennykh tekstiv $v$ ukrainskomu informatsiinomu prostori [Algorithm for neutralization of pathogenic texts in 
the Ukrainian information space], Odessa Linguistic School: Modern Paradigms: Collect. monograph, PolyPrynt, Odesa, Pp. 175 - 285.

8. Kovalevska, T. Yu. (2001), Komunikatyvni aspekty neirolinhvistychnoho prohramuvannia : Monohrafiia [Communicative aspects of neurolinguistic programming: Monograph], Astroprynt, Odesa, 344 p.

9. Kravchenko, O. V. (2009), Sintaksicheskie mekhanizmy porozhdeniya lingvisticheskogo absurda [Syntactic mechanisms for generating linguistic absurdity], Herald of the Russian State Pedagogical University. A.I. Herzen, Vol. 106, Pp. 141-146.

10. Potiatynyk, B., Lozynskyi, M. (1996), Patohennyi tekst [Pathogenic text], Missionary, Lviv, 296 p.

11. Semenov, D. I., Shusharina, G. A. (2011), Setevoy trolling kak vid kommunikativnoy deyatel'nosti [Network trolling as a form of communication], Int. journ. Of experiment. Education,. Vol. 8, Pp.135 - 136.

12. Slavova, L. L. (2012), Movna osobystist lidera u dzerkali politychnoi linhvopersonolohii : SShA - Ukraina : monohrafiia [Linguistic personality of a leader in the mirror of political linguopersonology: USA - Ukraine: monograph], I. Franko ZhSU Publishing House, Zhytomyr, 360 p.

13. Ekman, P. (2010), Psikhologiya lzhi. Obmani menya, esli smozhesh' [The psychology of lies. Fool me if you can], Piter, SPb, 304 p.

14. Christensson, P. Techterms Computer and Internet Terms Dictionary: «Flaming Definition». URL: https://techterms.com/definition/flaming.

15. Davis R. The English Rothschilds. Collins, London. 1983. 272 p. URL: https://mawaratytuger.angelstouch16.com/the-english-rothschilds-book-17581yw.php.

16. Kovalevska A. V. Information Wars' Pathogenic Texts Neutralization Algorithm. Notes on Ukrainian Linguistics = Opera in linguistica ukrainiana. 2018. Vol 25. Pp. $227-239$.

17. Kovalevska A. V. Spin-Doctoring in modern political discourse: linguistic aspect. Bulletin of V. N. Karazin Kharkiv National University. Philology series. Vol. 87. 2021. Pp. $90-96$.

18. Kovalevska T. \& Kovalevska A. Utilizing the Neurolinguistic Programming Technologies in Foreign languages Teaching Practice in Ukrainian Universities. Arab World English Journal: Special Issue on English in Ukrainian Context. 2020. Pp. 184 - 193. DOI: https://dx.doi.org/10.24093/awej/elt3.16

19. Kovalevska A., Kovalevska T., Kravchynska T., Hirna N. , L ysenko T. Modern methods and information and communication technologies in the system of teachers' training for vocational education institutions. AD ALTA: Journal of interdisciplinary research. Vol. 10. Issue 01-XVI. Ak. sdr. MAGNANIMITAS: Czech Republic, Hradec Krбlovй. 2021. Pp. 106 - 114.

20. Kovalevska A., Kovalevska T., Kutuza N., Lakomska I. Suggestion Algorithm in Advertisement Megadiscourse: Hypnotic Inductors Systematics. Journal of Language and Linguistic Studies, 17 (Special Issue 2). 2020. Pp. 1294 - 1307.

21. Langer W. C. Office of Strategic Services (OSS) Washington, D.C. With the collaboration of Prof. Henry A. Murr, Harvard Psychological Clinic, Dr. Ernst Kris, New School for Social Research, Dr. Bertram D. Lawin, New York Psychoanalytic Institute. A Psychological Analysis of Adolph Hitler. His Life and Legend. URL: http://web.archive.org/web/20050828111124/http://www.nizkor.org/hweb/people/h/hitleradolf/oss-papers/text/profile-index.html.

22. Spruds A. \& Rožukalne A. Internet Trolling as a hybrid warfare tool: the case of Latvia. Riga, LV: NATO Strategic. URL: https://www.stratcomcoe.org/internet-trollinghybrid-warfare-tool-case-latvia-0.

23. Stone B. \& Ritchel M. The Hand That Controls the Sock Puppet Could Get Slapped. The New York Times. July 16. 2007. URL: 
https://www.nytimes.com/2007/07/16/technology/16blog.html ex=1342238400\&en=9a3424 $961 \mathrm{f} 9 \mathrm{~d} 2163 \& \mathrm{ei}=5088 \&$ partner $=$ rssnyt $\&$ emc $=$ rss .

\section{А. В. Ковалевська-Славова, \\ ऽ.}

Одеський регіональний інститут державного управління Національної академї державного управління при Президентові Украӥни, кафедра української та іноземних мов

\section{НЕЙТРАМІЗАЦІЯ ПАТОГЕННИХ МЕГАДИСКУРСІВ: СТРАТЕГIЯ ТРОАIHГУ}

У статті, скерованій на унаочнення стратегій і тактик нейтралізації негативного ефекту патогенного політичного мегадискурсу, досліджено особливості лінгвістичної реалізації впливу на матеріалі промов політичних лідерів європейських країн та текстів новинного характеру і увиразнено специфіку стратегії тролінгу, метою якої $є$ або ескалація емоційності та неправдивості інформації, поданої в оригінальному тексті, або ж доведення поданої в оригінальному тексті інформації до абсурду, що уможливить максимальне зниження раціональності сприйняття початкового тексту, а згодом - i довіри як до оригінального тексту почасти, так і згодом до адресанта зазначених текстів. Оптимальним використання стратегії тролінгу є в рамках нейтралізації патогенних текстів, створених в парадигмі фейкових 3 огляду на скерованість цього типу текстів на подання завідомо неправдивої інформації для ескалації напруженості в інформаційному просторі та дестабілізації ситуації. Наведено приклади використання усіх тактик зазначеної стратегії (грубого (деструктивного) тролінгу або флеймінгу, конструктивного тролінгу, перебільшення / зменшення, вікі-тролінгу, тактики «великої брехні», тактики сокпаппетінгу), в яких дотримано усіх ознак оригінального патогенного тексту, включаючи домінантні впливові маркери, а також особливосте стратегії реалізації сугестивності оригінального тексту, що уможливлює (при поданні тексті тій самій цільовій аудиторії, яка уже зазнала впливу оригінального тексту) зменшення або нейтралізацію шкідливого впливу оригінального патогенного тексту. Також у роботі окреслено перспективи подальших досліджень у зазначеній галузі 3 огляду на іï принципову важливість як для виокремлення базових стратегії побудови патогенних текстів та глибинних механізмів їх формулювання і, відповідно, впливу на реципієнтів, а й способів протидії кожному з типів таких дискурсів, так і для оптимізації інформаційого простору України в умовах інформаційної війни.

Ключові слова: політичний мегадискурс, патогенний текст, стратегія нейтралізації, інформаційні війни, тролінг, нейролінгвістичне програмування, сугестія.

А. В. Ковалевская-Славова,

2 р р филол. наук, Одесский региональный институт государственного управления Национальной академии государственного управления при Президенте Украины, кафедра украинского и иностранных языков

\section{НЕЙТРААИЗАЦИЯ ПАТОГЕННЫХ МЕГАДИСКУРСОВ: СТРАТЕГИЯ ТРОААИНГА}

В статье, направленной на иллюстрацию стратегий и тактик нейтрализации негативного эффекта патогенного политического мегадискурса, исследованы особенности лингвистической реализации влияния на материале речей политических 
лидеров европейских стран и текстов новостного характера, а также подчеркнута специфика стратегии троллинга, целью которой является либо эскалация эмоциональности и ложности информации, представленной в оригинальном массиве, либо доведение представленной в оригинальном массиве информации до абсурда, что позволит максимально снизить рациональность восприятия исходного массива, а впоследствии - и доверие как к оригинальному массиву отчасти, так и впоследствии к адресанту указанных массивов. Оптимальным использование стратегии троллинга является в рамках нейтрализации патогенных массивов, созданных в парадигме фейковых, учитывая направленность этого типа массивов на предоставление заведомо ложной информации для эскалации напряженности в информационном пространстве и дестабилизации ситуации. Приведены примеры использования всех тактик указанной стратегии (грубого (деструктивного) троллинга или флейминга, конструктивного троллинга, преувеличения / уменьшения, вики-троллинга, тактики «большой лжи», тактики сокпаппетинга), в которых соблюдены все признаки оригинального патогенного массива, включая доминантные маркеры влияния, а также особливосте стратегии реализации внушаемости оригинального текста, что делает возможным (при представлении массива той же целевой аудитории, которая уже подверглась воздействию оригинального массива) уменьшение либо же нейтрализацию вредного воздействия оригинального патогенного массива. Также в работе намечены перспективы дальнейших исследований в указанной области, учитывая ее принципиальную важность как для выделения базовых стратегии построения патогенных массивов и глубинных механизмов их формулировки и, соответственно, влияния на реципиентов, так и способов противодействия каждом из типов таких мегадискурсов для оптимизации информационного пространства Украины в условиях информационной войны.

Ключевые слова: политический мегадискурс, патогенный текст, стратегия нейтрализации, информационные войны, троллинг, нейролингвистическое программирование, суггестия. 